A N N A LE S

UNIVER S T A T IS MARIAE CURIE-SKŁODOW S A LUBLIN - POLONIA

VOL. XXX, 3

SECTIO J

2017

Uniwersytet Przyrodniczo-Humanistyczny w Siedlcach. Wydział Humanistyczny

\title{
SŁAWOMIR SOBCZAK
}

slawomir.sobczak@uph.edu.pl

\section{Modele socjalizacji stosowane przez wychowawców w placówkach resocjalizacyjnych}

Socialisation Models Used by Educators in Social Rehabilitation Institutions

\section{STRESZCZENIE}

Niniejszy artykuł dotyczy sfery oddziaływań socjalizacyjnych w strukturze instytucjonalnej. Badań dotyczących preferencji poszczególnych typów socjalizacji dotychczas nie prowadzono. Funkcjonuje jedynie podstawa naukowa opisana w literaturze, prezentująca ujęcia teoretyczne poszczególnych sposobów oddziaływań socjalizacyjnych. Postanowiono z tego powodu utworzyć narzędzie, które skonstruowano z uwzględnieniem twierdzeń Schaffera, by na tej podstawie ustalić, jaki wzorzec z czterech odmian socjalizacji jest preferowany przez wychowawców z placówek resocjalizacyjnych. Jako cel wyznaczono określenie istotnie statystycznych różnic między stopniem akceptacji poszczególnych klas socjalizacji ze względu na płeć, staż i miejsce pracy wychowawców resocjalizujących. Przyjęto hipotezę, że istnieją istotne statystycznie różnice pomiędzy rangowaniem cech modeli socjalizacji ze względu na płeć, staż i miejsce pracy wychowawców resocjalizujących. Opracowanie stanowi perspektywę badawczą teoretycznego opisu rodzajów socjalizacji prezentowanych w literaturze.

Słowa kluczowe: socjalizacja; oddziaływanie wychowawców; resocjalizacja

Socjalizacja jest określana jako całokształt wpływu środowiska na jednostkę (Pytka 2005). Gdy jest ona świadoma, to mamy do czynienia z preferencjami tych, którzy oddziałują, zaś gdy to działanie jest nieświadome, to wówczas możemy mówić o czymś, co w teorii jest określane - np. przez Bronfenbrenera (1970) czy Bandurę (1973) - jako naśladownictwo lub modelowanie.

Sam termin „wpływ” oznacza przyczynowość, jakąś kierunkowość działania czegoś na coś. Takie rozumienie będzie sytuowało analizę socjalizacji w uję- 
ciach relacyjnych. Należy pamiętać, że więzi interpersonalne są zwrotne (Sobczak 2000). Nie tylko podmiot kieruje się do przedmiotu (w przypadku człowieka do innego podmiotu), ale także druga strona odpowiada relacją zwrotną i rzutuje na podmiot pierwotnie oddziałujący, który będzie raz podmiotem, a innym razem kresem relacji osobowej. Nie tylko rodzice socjalizują dziecko, ale i dzieci wywierają nacisk na rodziców. Tę kwestię w literaturze poruszali m.in. Zaborowski (1969) i Sobczak (2002). Jest to ważne rozróżnienie z teoretycznego i prakseologicznego punktu widzenia, gdyż wychowanek nie jest jedynie biernym odbiorcą informacji, ponieważ przez własne funkcjonowanie wymusza na wychowawcy określoną reakcję, a ten siłą faktu musi ustosunkować się do jego specyficznego „poruszania się" w świecie, albo je radykalnie modyfikując, albo zachowując autonomię jako podstawę socjalizacji. Tylko behawioryzm i koncepcje mu pokrewne uczynią z wychowanka bierny punkt odbiorczy, wprowadzą konformizujące zabiegi w celu uspołecznienia (Sobczak 2009).

Teorie o podstawie monistycznej (idealizm, materializm) tłumaczą, że indywidualny światopogląd czy sposób odbioru rzeczywistości jest skutkiem prestiżu kultury, która kształtuje człowieka. Nie sposób jest nie docenić tego faktu, ale należy wprowadzić stosowne rozróżnienia. Gdybyśmy zatrzymali się na twierdzeniu, że kultura kształtuje człowieka, to w ciągu przyczynowo-skutkowym kultura byłaby sytuowana przed pojawiającym się człowiekiem. A przecież człowiek był pierwszy $i$ to on tworzy kulturę $\mathrm{w}$ znaczeniu podmiotowym, kultura jest tworzona przez niego. W znaczeniu przedmiotowym kultura funkcjonuje niezależnie od jednostkowego człowieka, niejako modelując jego zachowania, choć jako taka jest bierna. Tylko człowiek jest aktywnym odbiorcą i odtwórcą tego, co w kulturze jest proponowane $i$ wybiera $z$ niej to, co jego zdaniem jest dla niego odpowiednie. Czasami bez zastanowienia i refleksji bierze z kultury to, co inni przedstawiają jako niezbędne do realizacji.

Wymieniając obiekty znaczące dla socjalizacji, określa się, że są to osoby i kultura, a w niej - normy, wartości, standardy. Jednostkowy człowiek przychodzi na świat w środowisku ludzi. To oni są pierwszymi przekazicielami tego, co w kulturze z ich punktu widzenia i pojmowania świata jest istotne i ważne. Skoro kultura sama się nie tworzy, tylko kreatywny i aktywny jest człowiek, należałoby wprowadzić dodatkowe rozróżnienie, że w socjalizacji wyłącznie człowiek oddziałuje w sposób bezpośredni albo pośredni przez kulturę. Nie trzeba znać twórcy dzieła, wystarczy, że pozna się to, co zaproponował w kulturze duchowej czy materialnej. Przyjęcie tego dorobku przez jednostkę spowoduje uwewnętrznienie tych treści na sposób percepcji odbiorcy. Wówczas będziemy mieli do czynienia z czymś, co Marks i Engels (1961) określili jako alienację, gdy dzieło przekracza twórcę, tzn. gdy zaczyna funkcjonować nie tyle własnym życiem, co w świadomości człowieka i sposobach wykorzystania go przez innych ludzi. 
Socjalizację dzieli się na pierwotną i wtórną. Ten podział wymaga skomentowania. Zazwyczaj socjalizację określa się jako uspołecznienie i przypisuje się jej wyłącznie pozytywne znaczenie, mając przede wszystkim na myśli internalizację społecznie akceptowanych norm i wartości. Gdy mamy do czynienia z socjalizacją pierwotną, to przyjmujemy, że dotyczy ona wpływu środowiska rodzinnego. Nie zawsze takie oddziaływanie jest pozytywne, ponieważ rodzice niekoniecznie muszą przekazywać dziecku standardy życia akceptowanego społecznie i wtedy dziecko nabywa nawyki niepożądane. Czapów (1978) określa ten stan jako zwichniętą socjalizację. Funkcjonowanie tak ukształtowanej jednostki odbiega od oczekiwanych wzorców. Czy w tym przypadku dziecko w ogóle nie podlega socjalizacji, czyli wpływowi środowiska na jednostkę, czy raczej socjalizacja nie zmierza do internalizacji powszechnie obowiązujących norm życia codziennego? W tej sytuacji mamy do czynienia z socjalizacją, która nie prowadzi do tego, co jesteśmy skłonni określić jako uspołecznienie w znaczeniu normy skodyfikowanej (umowy społecznej). Takie oddziaływanie nie przebiega pozytywnie w randze społecznie oczekiwanej. Jednak socjalizacja zachodzi zawsze, ale może być wadliwa, niezgodna z oczekiwaniami społecznymi. Dlatego trudno jest twierdzić, oczywiście w aspektach uspołecznienia pożądanego społecznie (klasyczne rozumienie socjalizacji), że socjalizacja jest wyłącznie uspołecznieniem normatywnym; raczej jest ona sposobem uczenia się, jak funkcjonować w społeczeństwie. Sposoby te mogą być różne - takie, które odpowiadają temu, co się określa jako prawidłowe funkcjonowanie lub takie, które do takich skutków nie zmierzają. Natomiast socjalizacja zawsze prowadzi do zachowania własnej egzystencji w środowisku osób, specyficznego odnalezienia się i przetrwania wśród innych ludzi (norma ekologiczna).

Z podobną kwestią spotykamy się, gdy mówimy o socjalizacji wtórnej, która obejmuje różnego typu oddziaływania środowiskowe, w tym instytucjonalne. Ten typ uspołecznienia należy pojmować dwojako, gdyż w tym przypadku mamy do czynienia z dwoma rodzajami socjalizacji. Pierwszym z nich jest socjalizacja w aspektach środowiskowych, poza rodzinnymi. Tu zachodzi sytuacja analogiczna, jak w okolicznościach uspołecznienia pierwotnego. Negatywny wpływ środowiska na jednostkę jest od dawna szeroko dyskutowany w pedagogice resocjalizacyjnej, np. Czapów (1978) wymienia dwa jego atrybuty: demoralizację i socjalizację podkulturową. Problemy związane $\mathrm{z}$ oddziaływaniem środowiska na jednostkę rozpatrywane są także w koncepcjach resilience, określających czynniki chroniące $\mathrm{w}$ różnych aspektach środowiskowych i indywidualnych, przeciwdziałające zachowaniom ryzykownym (Sobczak 2011). Drugim typem socjalizacji wtórnej jest oddziaływanie instytucjonalne. Ten rodzaj rzutowania powinien mieć zawsze charakter pozytywny. Inną stronę medalu stanowi pytanie, czy rzeczywiście tak jest, czy instytucje spełniają w sposób należyty swoje funkcje. Niestety, to nie instytucje socjalizują, tylko człowiek przypisany do instytucji, a ten przekaże 
tylko to, co sam w sobie ukształtował na skutek określonych warunków społeczno-kulturowych. Ponadto należy dodać, że wychowawcy lub nauczyciele postępują lub przynajmniej powinni postępować zgodnie z prawem. Gdy jest ono wadliwie skonstruowane, to w konsekwencji oddziaływanie socjalizacyjne w takiej instytucji jest nieprawidłowe. Ta kwestia stanowi oddzielne zagadnienie.

W związku z powyższymi treściami należałoby się zastanowić, czy nie przyjąć podziału socjalizacji na środowiskową i instytucjonalną. Szczególnie aspekt oddziaływań instytucjonalnych jest istotny, gdyż tu powinno następować uzupełnianie lub wyrównywanie tych braków, które powstały na skutek oddziaływania środowiskowego.

W badaniach będziemy mieli do czynienia z socjalizacją wtórną na poziomie instytucjonalnym o relacji jednokierunkowej, gdyż osoby badane to wychowawcy, którzy w pracy resocjalizacyjnej zgodnie ze swoim przekonaniem, wiedzą i własnym poziomem uspołecznienia socjalizują osoby nieprzystosowane społecznie.

\section{ZASTOSOWANA METODOLOGIA}

W niniejszych badaniach posłużono się metodą sondażową, jako technikę zastosowano socjometrię, zaś narzędziem był autorski kwestionariusz skonstruowany do zbadania cech modeli socjalizacji. Został on zbudowany w oparciu o teorię Schaffera (2006), który wyróżnia cztery modele socjalizacji: zupełnej swobody, lepienia z gliny, konfliktowy i wzajemności. W kwestionariuszu do każdego typu badanej socjalizacji były przypisane trzy jego specyficzne cechy. Zadaniem respondenta było oszacowanie na skali utworzonej przez Likerta (1932), w jakim stopniu preferuje daną cechę. Skala składała się z pięciu poziomów możliwości. Badana osoba musiała zdecydować, czy akceptuje wyznaczoną cechę na poziomie: zdecydowanie tak (5), raczej tak (4), nie mam pewności (3), raczej nie (2), zdecydowanie nie (1).

Badane cechy modelu socjalizacji:

1. Lepienia z gliny:

- cecha 1: jedynie wychowawca w procesie socjalizacji jest aktywny, kształtuje wychowanka, kreuje jego odpowiedni rozwój,

- cecha 2: wychowawca w procesie socjalizacji kształtuje nawyki wychowanka,

- cecha 3: wychowanek jest biernym uczestnikiem procesu socjalizacji, a jego osobowość jest plastyczna, dlatego wychowawca nadaje jej właściwy wymiar.

2. Wzajemności:

- cecha 1: wychowawca nie powinien traktować wychowanka jako biernego uczestnika procesu socjalizacji, lecz ma spowodować, aby brał w nim aktywny udział, 
- cecha 2: wychowawca powinien dopasować się do wychowanka,

- cecha 3: wychowawca bez zgody wychowanka nie powinien nakłaniać go do czegokolwiek.

3. Konfliktowy:

- cecha 1: wychowawca powinien poskromić postępowanie wychowanka będące w opozycji do zasad przyjętych w społeczeństwie,

- cecha 2: wychowawca powinien zmusić wychowanka do porzucenia swoich nieprawidłowych nawyków oraz przyjęcia wzorców zachowań, które są społecznie akceptowane,

- cecha 3: człowiek zgodnie ze swoją naturą posiada impulsywne odruchy, dlatego wychowawca powinien hamować prymitywne zachowania wychowanka.

4. Zupełnej swobody:

- cecha 1: wychowawca powinien ograniczyć swój wpływ na wychowanka, ponieważ w procesie socjalizacji ma do spełnienia jedynie niewielką rolę,

- cecha 2: zadaniem wychowawcy jest nieprzeszkadzanie wychowankowi w rozwoju, który powinien mieć charakter zupełnej swobody,

- cecha 3: działanie wychowawcy podejmowane jest tylko i wyłącznie w celu stworzenia dogodnego otoczenia, w którym wychowanek samodzielnie będzie rozwijał swój potencjał.

Tab. 1. Zmienne i ich wskaźniki

\begin{tabular}{|l|l|l|c|}
\hline \multicolumn{1}{|c|}{ Zmienna niezależna } & \multicolumn{1}{|c|}{ Wskaźniki } & \multicolumn{1}{|c|}{ Zmienna zależna } & Wskaźniki \\
\hline Płeć & $\begin{array}{l}\text { Kobieta } \\
\text { Mężczyzna }\end{array}$ & $\begin{array}{l}\text { Modele socjalizacji: } \\
\text { lepienia z gliny }\end{array}$ & $\begin{array}{l}\text { Cecha 1 } \\
\text { Cecha 2 } \\
\text { Cecha 3 }\end{array}$ \\
\hline Rodzaj wykształcenia & $\begin{array}{l}\text { Wykształcenie resocjalizacyjne } \\
\text { Wykształcenie inne niż } \\
\text { resocjalizacyjne }\end{array}$ & $\begin{array}{l}\text { Modele socjalizacji: } \\
\text { wzajemności }\end{array}$ & $\begin{array}{l}\text { Cecha 1 } \\
\text { Cecha 2 } \\
\text { Cecha 3 }\end{array}$ \\
\hline $\begin{array}{l}\text { Staż pracy z młodzieżą } \\
\text { nieprzystosowaną spo- } \\
\text { łecznie }\end{array}$ & $\begin{array}{l}\text { Do 5 lat } \\
\text { Od 6 do 10 lat } \\
\text { Powyżej 10 lat }\end{array}$ & $\begin{array}{l}\text { Modele socjalizacji: } \\
\text { konfliktowy }\end{array}$ & $\begin{array}{l}\text { Cecha 1 } \\
\text { Cecha 2 } \\
\text { Cecha 3 }\end{array}$ \\
\hline Miejsce zatrudnienia & $\begin{array}{l}\text { Młodzieżowy Ośrodek } \\
\text { Wychowawczy } \\
\text { Młodzieżowy Ośrodek } \\
\text { Socjoterapeutyczny } \\
\text { Zakład Poprawczy }\end{array}$ & $\begin{array}{l}\text { Modele socjalizacji: } \\
\text { zupełnej swobody }\end{array}$ & $\begin{array}{l}\text { Cecha 1 } \\
\text { Cecha 2 } \\
\text { Cecha 3 }\end{array}$ \\
\hline
\end{tabular}

Źródło: opracowanie własne. 
W badaniach zmienną niezależną były: płeć, rodzaj wykształcenia, staż i zakład pracy respondentów, natomiast zmienną zależną były poszczególne modele socjalizacji.

Przedmiotem badań była opinia wychowawców resocjalizujących dotycząca preferencji poszczególnych cech czterech modeli socjalizacji.

Celem badań była identyfikacja dominującego modelu socjalizacji wśród wychowawców z ośrodków resocjalizacyjnych oraz ustalenie różnic statystycznie istotnych pomiędzy preferowaniem przez respondentów poszczególnych cech typów socjalizacji a ich płcią, wykształceniem, stażem i miejscem pracy.

Do tak sformułowanego celu przyjęto następujące problemy badawcze:

1. Jaki jest dominujący model socjalizacji wśród wychowawców z placówek resocjalizacyjnych?

2. Czy występują istotne statystycznie różnice pomiędzy preferowaniem przez respondentów poszczególnych cech typów socjalizacji a ich płcią, wykształceniem, stażem i miejscem pracy?

$\mathrm{Z}$ ustalonych pytań badawczych przyjęto hipotezę zerową (H0): różnice pomiędzy preferowaniem przez respondentów poszczególnych cech typów socjalizacji a ich płcią, wykształceniem, stażem i zakładem pracy są statystycznie nieistotne.

W badaniach statystycznych posłużono się analizą parametryczną, gdyż przyjęte zmienne zależne po przekształceniu miały charakter ilościowy, gdzie rozkład był normalny oraz wystąpiła równoliczność badanych prób. Standaryzacja pozwoliła na manipulację danymi pochodzącymi z kwestionariusza, mianowicie wyniki skali Likerta przekształcono na rozkłady od ujemnego do dodatniego, gdzie średnia jest zerem. Istotność różnic obliczono za pomocą testu t-Studenta.

\section{BADANE OSOBY}

Badania przeprowadzono $\mathrm{w}$ placówkach resocjalizacyjnych w województwie mazowieckim. Zbadano wychowawców z ośrodków wychowawczych, socjoterapeutycznych i zakładów poprawczych. Dobór próby był losowy. Przebadano jedynie osoby z placówek państwowych. W artykule, aby nie stosować długich nazw miejsca pracy respondentów, zastosowano następujące skróty: MOW - Młodzieżowy Ośrodek Wychowawczy, MOS - Młodzieżowy Ośrodek Socjoterapeutyczny, ZP - Zakład Poprawczy. 
Tab. 2. Statystyki badanych osób

\begin{tabular}{|l|c|c|c|c|c|c|r|r|}
\hline \multirow{2}{*}{ Zakład pracy } & \multicolumn{2}{|c|}{ MOW } & \multicolumn{2}{c|}{ MOS } & \multicolumn{2}{c|}{ ZP } & \multicolumn{2}{c|}{ Ogółem } \\
\hline Badane osoby & $\mathrm{N}$ & $\%$ & $\mathrm{~N}$ & $\%$ & $\mathrm{~N}$ & $\%$ & $\mathrm{~N}$ & $\%$ \\
\hline Ogółem & 50 & 33,33 & 50 & 33,33 & 50 & 33,33 & 150 & 100 \\
\hline Kobieta & 27 & 18 & 26 & 17 & 19 & 13 & 72 & 48 \\
\hline Mężczyzna & 23 & 15 & 24 & 16 & 31 & 21 & 78 & 52 \\
\hline Wykształcenie resocjalizacyjne & 27 & 18 & 30 & 20 & 32 & 21 & 89 & 59 \\
\hline Wykształcenie inne niż resocjalizacyjne & 23 & 15 & 20 & 14 & 18 & 12 & 61 & 41 \\
\hline Staż pracy do 5 lat & 11 & 7 & 13 & 9 & 11 & 7 & 35 & 23 \\
\hline Staż pracy od 6 do 10 lat & 19 & 13 & 18 & 12 & 19 & 13 & 56 & 38 \\
\hline Staż pracy powyżej 10 lat & 20 & 13 & 19 & 13 & 20 & 13 & 59 & 39 \\
\hline
\end{tabular}

Źródło: opracowanie własne.

W badaniach wzięło udział 150 respondentów - po 50 osób z każdego środowiska, co stanowiło po $33,33 \%$ badanych. Byli to wychowawcy pracujący w ośrodkach o charakterze resocjalizacyjnym: MOS, MOW i ZP.

Wychowawcy zostali podzieleni ze względu na płeć. Wszystkich kobiet biorących udział w ankietyzacji było 72 , co stanowi $48 \%$ ogółu badanych. W MOS pracowało 27 kobiet, czyli 18\%. Z MOW było 26 kobiet, co stanowi 17\%. Z ZP wywodziło się 19 kobiet, co odpowiada 13\% próby. Mężczyzn było 78, co stanowi 52\% wszystkich respondentów. Z MOS rekrutowało się 23 mężczyzn, czyli $15 \%$. W MOW wykonywało pracę 24 mężczyzn, co stanowi 16\% grupy, zaś z ZP - 31 mężczyzn, co odpowiada $21 \%$ badanych.

Wykształcenie wychowawców rozkładało się w następujący sposób. Osób, które zadeklarowały ukończenie studiów w zakresie pedagogiki resocjalizacyjnej, było 89 , czyli 59\% badanych. Z MOS było ich 27 , co odpowiada $18 \%$ respondentów. Z MOW było 30 opiniodawców, co stanowi $20 \%$ grupy. Z ZP pochodziły 32 osoby $-21 \%$ wszystkich ankietowanych. Wychowawców, którzy oświadczyli, że ukończyli studia inne niż w zakresie pedagogiki resocjalizacyjnej, było 61, czyli $41 \%$. Z MOS pochodziło 23 respondentów, czyli 15\%. Z MOW wywodziło się 20 osób, co stanowi 14\%. Z ZP było 18 respondentów, co odpowiada $12 \%$ badanych.

Ponadto wychowawcy zostali podzieleni ze względu na staż pracy. Respondentów pracujących w placówkach resocjalizacyjnych do 5 lat było 35 osób (23\% ogółu badanych). W MOS pracowało 11 osób, którzy stanowili 7\% opiniodawców. Z MOW było ich 13, co odpowiada $9 \%$ analizowanej próby. Z ZP wywodziło się 11 osób (7\% respondentów). Ankietowanych ze stażem pracy od 6 do 10 
lat było 56, co odpowiada 38\% wszystkich badanych. Z MOS rekrutowało się 19 osób, czyli $13 \%$ całości. Z MOW takich osób było 18, czyli 12\%. Z ZP pochodziło 19 osób, co stanowi 13\% grupy. Respondentów ze stażem powyżej 10 lat pracy było 59, co odpowiada $39 \%$ ogółu badanych. W MOS pracowało 20 osób, czyli $13 \%$. Z MOW takich osób było 19, co odpowiada 13\%. W ZP pracowało 20 wychowawców, czyli 13\% wszystkich opiniodawców.

\section{ANALIZA WYNIKÓW BADAŃ}

Model socjalizacji lepienia z gliny był najwyżej zaopiniowany z sumą $(2,13)$. Drugim typem akceptowanym przez badane osoby na poziomie $(1,41)$ jest model wzajemności. Warianty, które zostały odrzucone przez respondentów, to: sposób oddziaływań konfliktowy przyjęty z rangą $(-0,08)$ oraz rodzaj socjalizacji zupełnej swobody, najniżej usankcjonowany, $z$ kategorią $(-3,36)$.

Standaryzacja dla poszczególnych cech badanych modeli wypadła w następujący sposób. Najwyżej akceptowanymi cechami socjalizacji są dwa atrybuty modelu lepienia $\mathrm{z}$ gliny: cecha 1 osiągnęła wartość $(1,57)$, poziom cechy 2 to $(1,36)$, zaś cecha 3 tego modelu nie została zaaprobowana - jej wskaźnik wynosi $(-0,80)$. W modelu wzajemności wszystkie cechy były zaopiniowane pozytywnie: cecha 1 osiągnęła wynik $(1,04)$, cechę 3 przyjęto na poziomie $(0,35)$, cecha 2 została sklasyfikowana z kategorią $(0,02)$. W rodzaju socjalizacji konfliktowej tylko cecha 2 uzyskała pozytywną opinię z sumą $(0,31)$, natomiast cechy 1 i 3 respondenci odrzucili, cechę 3 była na poziomie $(-0,19)$, natomiast cecha 1 uzyskała wartość minimalnie niższą $(-0,20)$. W typie zupełnej swobody wszystkie cechy tego rodzaju socjalizacji zostały odrzucone. Najniżej została oceniona cecha 1 na poziomie $(-1,60)$, cecha 2 przyjęła wartość $(-1,47)$, cecha 3 została zaopiniowana z wynikiem $(-0,29)$.

Tab. 3. Ocena poszczególnych cech modeli socjalizacji wskazanych przez wychowawców z ośrodków resocjalizacyjnych

\begin{tabular}{|l|c|c|c|c|}
\hline \multicolumn{1}{|c|}{ Model socjalizacji } & Cecha 1 & Cecha 2 & Cecha 3 & Suma \\
\hline Lepienia z gliny & 1,57 & 1,36 & $-0,80$ & 2,13 \\
\hline Wzajemności & 1,04 & 0,02 & 0,35 & 1,41 \\
\hline Konfliktowy & $-0,20$ & 0,31 & $-0,19$ & $-0,08$ \\
\hline Zupełnej swobody & $-1,60$ & $-1,47$ & $-0,29$ & $-3,36$ \\
\hline
\end{tabular}

Źródło: opracowanie własne. 
Łącznie sześć cech spośród wszystkich typów socjalizacji było przez wychowawców zaaprobowanych i sześć cech zostało przez nich ocenionych negatywnie. Każdy wybierany aspekt modelu wzajemności został przyjęty pozytywnie. W rodzaju socjalizacji zupełnej swobody poszczególne cechy tego modelu były odrzucone. W modelu lepienia $\mathrm{z}$ gliny cecha 3 nie została zaakceptowana, zaś w modelu konfliktowym tylko cecha 2 uzyskała pozytywną rekomendację respondentów.

Tab. 4. Ocena poszczególnych cech modelu socjalizacji lepienia z gliny ze względu na płeć, wykształcenie, staż i zakład pracy badanych wychowawców

\begin{tabular}{|l|c|c|c|c|}
\hline \multicolumn{1}{|c|}{ Model socjalizacji lepienia z gliny } & Cecha 1 & Cecha 2 & Cecha 3 & Suma \\
\hline Badane osoby & 1,57 & 1,36 & $-0,80$ & 2,13 \\
\hline Kobieta & 1,62 & 1,29 & $-1,03$ & 1,88 \\
\hline Mężczyzna & 1,48 & 1,40 & $-0,58$ & 2,30 \\
\hline Wykształcenie w zakresie resocjalizacji & 1,49 & 1,47 & $-0,64$ & 2,32 \\
\hline Wykształcenie inne niż resocjalizacyjne & 1,65 & 1,13 & $-1,03$ & 1,75 \\
\hline Staż pracy do 5 lat & 1,85 & 1,60 & $-0,89$ & 2,56 \\
\hline Staż pracy od 6 do 10 lat & 1,54 & 1,30 & $-1,04$ & 1,80 \\
\hline Staż pracy powyżej 10 lat & 1,35 & 1,20 & $-0,45$ & 2,10 \\
\hline MOW & 1,51 & 1,51 & $-0,78$ & 2,24 \\
\hline MOS & 1,54 & 1,54 & $-0,87$ & 2,21 \\
\hline ZP & 1,51 & 0,66 & $-0,61$ & 1,56 \\
\hline
\end{tabular}

Źródło: opracowanie własne.

Wychowawcy płci męskiej wybrali typ lepienia z gliny na poziomie $(2,30)$, zaś kobiety dokonały preferencji opisywanego modelu z wynikiem $(1,88)$. Mężczyźni częściej niż kobiety wskazywali na ten rodzaj socjalizacji.

Respondenci z wykształceniem w zakresie pedagogiki resocjalizacyjnej odnieśli się do modelu lepienia $\mathrm{z}$ gliny $\mathrm{z}$ wynikiem $(2,32)$, natomiast wychowawcy $\mathrm{z}$ wykształceniem innym niż $\mathrm{w}$ zakresie pedagogiki resocjalizacyjnej określili omawiany typ na poziomie $(1,75)$. Wychowawcy $\mathrm{z}$ wykształceniem $\mathrm{w}$ zakresie pedagogiki resocjalizacyjnej częściej niż ankietowani z wykształceniem innym niż w zakresie pedagogiki resocjalizacyjnej wybierali ten rodzaj socjalizacji.

Ze względu na staż wychowawczy należy wskazać, że osoby, które przepracowały do 5 lat, najczęściej ze wszystkich badanych grup pozytywnie ustosunkowywały się do modelu lepienia z gliny - dla nich suma poszczególnych cech 
wyniosła $(2,56)$. Kolejną grupą byli respondenci z najwyższym stażem, czyli powyżej 10 lat pracy. Wskazali oni stopień aprobaty charakteryzowanego modelu na poziomie $(2,10)$. Wychowawcy ze stażem pracy od 6 do 10 lat najniżej spośród grup z uwzględnieniem stażu pracy zaopiniowali model lepienia z gliny $-\mathrm{z}$ kategorią $(1,80)$.

Analiza wyników poszczególnych cech modelu lepienia z gliny dowodzi, że najbardziej ten typ oddziaływań został zaakceptowany przez respondentów z MOW, gdyż na poziomie $(2,24)$, następnie przez wychowawców z MOS z sumą $(2,21)$. Najmniej był on ceniony przez pracowników z ZP z kategorią $(1,56)$. Cechy 1 i 2 zostały zaaprobowane przez wszystkich wychowawców, zaś cecha 3 tego modelu została przez ogół respondentów zaopiniowana negatywnie.

Tab. 5. Istotność różnic pomiędzy wyborem poszczególnych cech modelu socjalizacji lepienia z gliny a płcią, wykształceniem, stażem i zakładem pracy badanych wychowawców

\begin{tabular}{|l|c|c|c|}
\hline \multicolumn{1}{|c|}{ Model socjalizacji } & \multicolumn{3}{c|}{ Istotność dwustronna } \\
\hline Lepienia z gliny & Cecha 1 & Cecha 2 & Cecha 3 \\
\hline Płeć & 0,928 & 0,493 & 0,142 \\
\hline Wykształcenie & 0,717 & 0,089 & 0,340 \\
\hline Staż pracy do 5 lat*6-10 lat & 0,397 & 0,547 & 0,600 \\
\hline Staż pracy do 5 lat*powyżej 10 lat & 0,103 & 0,322 & 0,319 \\
\hline Staż pracy od 6-10 lat*powyżej 10 lat & 0,327 & 0,672 & 0,068 \\
\hline Zakład pracy MOW*MOS & 0,741 & 0,814 & 0,831 \\
\hline Zakład pracy MOW*ZP & 0,398 & 0,032 & 0,027 \\
\hline Zakład pracy MOS*ZP & 0,266 & 0,018 & 0,017 \\
\hline
\end{tabular}

Źródło: opracowanie własne.

Różnice statystycznie istotne zachodzą w przypadku wyborów cechy 2 i 3 wśród wskazań pracowników z MOW*ZP i MOS*ZP. Wychowawcy z ZP istotnie statystycznie niżej aprobowali cechę 2 i 3 modelu socjalizacji lepienia z gliny niż pracownicy MOW i MOS. 
Tab. 6. Ocena poszczególnych cech modelu socjalizacji wzajemności ze względu na płeć, wykształcenie, staż i zakład pracy badanych wychowawców

\begin{tabular}{|l|c|c|c|c|}
\hline \multicolumn{1}{|c|}{ Model socjalizacji wzajemności } & Cecha 1 & Cecha 2 & Cecha 3 & Suma \\
\hline Badane osoby & 1,04 & 0,02 & 0,35 & 1,41 \\
\hline Kobieta & 1,09 & 0,01 & 0,33 & 1,43 \\
\hline Mężczyzna & 0,96 & 0,04 & 0,37 & 1,37 \\
\hline Wykształcenie w zakresie resocjalizacji & 1,06 & 0,02 & 0,30 & 1,38 \\
\hline Wykształcenie inne niż resocjalizacyjne & 0,96 & 0,03 & 0,42 & 1,41 \\
\hline Staż pracy do 5 lat & 0,93 & 0,10 & 0,22 & 1,25 \\
\hline Staż pracy od 6 do 10 lat & 0,97 & $-0,02$ & 0,36 & 1,31 \\
\hline Staż pracy powyżej 10 lat & 1,11 & 0,02 & 0,41 & 1,54 \\
\hline MOW & 1,22 & 0,02 & 0,22 & 1,46 \\
\hline MOS & 0,95 & 0,24 & 0,31 & 1,50 \\
\hline ZP & 0,74 & $-0,30$ & 0,58 & 1,02 \\
\hline
\end{tabular}

Źródło: opracowanie własne.

Wychowawcy płci męskiej wybrali model wzajemności na poziomie $(1,37)$, zaś suma analizowanego typu dla kobiet wyniosła $(1,43)$. Kobiety częściej niż mężczyźni wskazywały na ten rodzaj socjalizacji.

Respondenci z wykształceniem w zakresie pedagogiki resocjalizacyjnej odnieśli się do socjalizacji o charakterze wzajemności z wynikiem $(1,38)$, natomiast ankietowani z wykształceniem innym niż w zakresie pedagogiki resocjalizacyjnej określili omawiany typ na poziomie $(1,41)$. Wychowawcy z wykształceniem innym niż w zakresie pedagogiki resocjalizacyjnej częściej niż opiekunowie z wykształceniem w zakresie pedagogiki resocjalizacyjnej wybierali model wzajemności.

Ze względu na staż pracy trzeba wskazać, że zatrudnieni w instytucji do 5 lat najrzadziej ze wszystkich badanych grup pozytywnie ustosunkowywali się do typu wzajemności - dla nich suma wyniosła $(1,25)$. Kolejną grupą, nieco wyżej oceniającą ten wariant oddziaływań, były osoby ze stażem pracy od 6 do 10 lat oni wskazali go na poziomie $(1,31)$. Pracownicy ze stażem powyżej 10 lat najwyżej zaopiniowali omawiany model - z kategorią $(1,54)$.

Analiza rezultatów preferencji poszczególnych cech modelu wzajemności ujawnia, że najwyżej został on zaakceptowany przez respondentów z MOS, gdyż na poziomie $(1,50)$, a następnie przez wychowawców z MOW z sumą $(1,46)$. Najmniej był on ceniony przez pracowników z ZP - z kategorią $(1,02)$.

Cechy 1 i 3 modelu wzajemności zostały zaaprobowane w procesie socjalizacji przez wszystkich wychowawców, zaś cecha 2 była odrzucona tylko przez re- 
spondentów ze stażem od 6 do 10 lat pracy na poziomie $(-0,02)$ oraz przez wychowawców z ZP z wynikiem (-0,30).

Tab. 7. Istotność różnic pomiędzy wyborem poszczególnych cech modelu socjalizacji wzajemności a płcią, wykształceniem, stażem i zakładem pracy badanych wychowawców

\begin{tabular}{|l|c|c|c|}
\hline \multicolumn{1}{|c|}{ Model socjalizacji } & \multicolumn{3}{c|}{ Istotność dwustronna } \\
\hline Wzajemności & Cecha 1 & Cecha 2 & Cecha 3 \\
\hline Płeć & 0,913 & 0,806 & 0,719 \\
\hline Wykształcenie & 0,396 & 0,901 & 0,938 \\
\hline Staż pracy do 5 lat*6-10 lat & 0,858 & 0,767 & 0,736 \\
\hline Staż pracy do 5 lat*powyżej 10 lat & 0,678 & 0,902 & 0,608 \\
\hline Staż pracy od 6-10 lat*powyżej 10 lat & 0,785 & 0,838 & 0,870 \\
\hline Zakład pracy MOW*MOS & 0,461 & 0,440 & 0,699 \\
\hline Zakład pracy MOW*ZP & 0,225 & 0,651 & 0,142 \\
\hline Zakład pracy MOS*ZP & 0,613 & 0,793 & 0,258 \\
\hline
\end{tabular}

Źródło: opracowanie własne.

Na podstawie testu t-Studenta można stwierdzić, że nie występują istotne statystycznie różnice pomiędzy wyborem poszczególnych cech modelu socjalizacji wzajemności a płcią, wykształceniem, stażem i miejscem pracy wychowawców.

Tab. 8. Ocena poszczególnych cech modelu socjalizacji konfliktowej ze względu na płeć, wykształcenie, staż i zakład pracy badanych wychowawców

\begin{tabular}{|l|c|c|c|c|}
\hline \multicolumn{1}{|c|}{ Model socjalizacji konfliktowy } & Cecha 1 & Cecha 2 & Cecha 3 & Suma \\
\hline Badane osoby & $-0,20$ & 0,31 & $-0,19$ & $-0,08$ \\
\hline Kobieta & $-0,44$ & 0,09 & $-0,40$ & $-0,75$ \\
\hline Mężczyzna & 0,02 & 0,51 & 0,00 & 0,53 \\
\hline Wykształcenie w zakresie resocjalizacji & $-0,14$ & 0,40 & $-0,03$ & 0,23 \\
\hline Wykształcenie inne niż resocjalizacyjne & $-0,29$ & 0,15 & $-0,44$ & $-0,58$ \\
\hline Staż pracy do 5 lat & $-0,02$ & $-0,14$ & $-0,14$ & $-0,30$ \\
\hline Staż pracy od 6 do 10 lat & $-0,19$ & 0,17 & $-0,12$ & $-0,14$ \\
\hline Staż pracy powyżej 10 lat & $-0,31$ & 0,72 & $-0,29$ & $-0,12$ \\
\hline MOW & $-0,28$ & 0,20 & $-0,25$ & $-0,33$ \\
\hline MOS & $-0,38$ & 0,29 & $-0,42$ & $-0,51$ \\
\hline ZP & 0,24 & 0,51 & 0,31 & 1,06 \\
\hline
\end{tabular}

Źródło: opracowanie własne. 
Wychowawcy płci męskiej wybrali model konfliktowy na poziomie $(0,53)$, zaś suma tego rodzaju socjalizacji dla kobiet wyniosła (-0,75). Mężczyźni częściej niż kobiety wskazywali na ten typ oddziaływania. Ponadto mężczyźni pozytywnie zaopiniowali swoje podejście do modelu konfliktowego, podczas gdy kobiety odrzuciły taki sposób socjalizacji.

Respondenci $\mathrm{z}$ wykształceniem $\mathrm{w}$ zakresie pedagogiki resocjalizacyjnej wskazywali na socjalizację o charakterze konfliktowym $\mathrm{z}$ wynikiem $(0,23)$, natomiast ankietowani z wykształceniem innym niż w zakresie pedagogiki resocjalizacyjnej określili omawiany typ na poziomie $(-0,58)$. Wychowawcy z wykształceniem w zakresie pedagogiki resocjalizacyjnej częściej niż ankietowani z wykształceniem innym niż w zakresie pedagogiki resocjalizacyjnej wybierali ten sposób socjalizacji. Respondenci z wykształceniem innym niż w zakresie pedagogiki resocjalizacyjnej negatywnie zaopiniowali oddziaływanie o charakterze konfliktowym, z kolei wychowawcy z wykształceniem z zakresu pedagogiki resocjalizacyjnej odnieśli się do omawianego zjawiska pozytywnie.

Biorąc pod uwagę staż, respondenci, którzy przepracowali w ośrodku do 5 lat najczęściej ustosunkowywali się negatywnie do modelu konfliktowego, ponieważ dla ich wyborów suma wyników wyniosła $(-0,30)$. Pracownicy ze stażem od 6 do 10 lat wskazali na analizowany typ socjalizacji na poziomie $(-0,14)$. Wychowawcy ze stażem pracy powyżej 10 lat zaopiniowali ten wzorzec z oceną $(-0,12)$. Wszystkie opisywane grupy nie zaakceptowały modelu socjalizacji konfliktowej. Poziom dezaprobaty dla tego modelu malał w zależności od liczby lat przepracowanych przez wychowawcę w placówce.

Najwyżej typ konfliktowy został zaakceptowany przez respondentów z ZP, bo na poziomie $(1,06)$, natomiast osoby z pozostałych instytucji negatywnie się do niego odniosły. Ankietowani z MOW ustosunkowali się do takiej socjalizacji $z$ sumą $(-0,33)$. Najmniej ten rodzaj oddziaływania był doceniany przez pracowników z MOS, gdyż z kategorią (-0,51).

Zasadniczo cechy 1 i 3 zostały odrzucone przez wychowawców, zaś cecha 2 tego modelu była przez respondentów zaaprobowana, $z$ tym że cechę 1 pozytywnie przyjęli wychowawcy płci męskiej oraz osoby pracujące w ZP, a pozostałe badane grupy ją odrzuciły. Cechę 2 negatywnie przyjęli wyłącznie pracownicy ze stażem do 5 lat, przez pozostałych respondentów została ona zaakceptowana. Cechę 3 zaaprobowały tylko osoby pracujące w ZP, natomiast mężczyźni w ocenie tego atrybutu osiągnęli poziom ambiwalentny $(0,00)$. Wszystkie cechy modelu socjalizacji konfliktowej były zaakceptowane przez mężczyzn i osoby pracujące w ZP. Tylko wychowawcy ze stażem do 5 lat pracy wszystkie cechy tego modelu odrzucili. 
Tab. 9. Istotność różnic pomiędzy wyborem poszczególnych cech modelu socjalizacji konfliktowej a płcią, wykształceniem, stażem i zakładem pracy badanych wychowawców

\begin{tabular}{|l|c|c|c|}
\hline \multirow{2}{*}{ Model socjalizacji } & \multicolumn{3}{c|}{ Istotność dwustronna } \\
\hline Konfliktowy & Cecha 1 & Cecha 2 & Cecha 3 \\
\hline Płeć & 0,120 & 0,147 & 0,201 \\
\hline Wykształcenie & 0,617 & 0,327 & 0,251 \\
\hline Staż pracy do 5 lat*6-10 lat & 0,659 & 0,502 & 0,991 \\
\hline Staż pracy do 5 lat*powyżej 10 lat & 0,548 & 0,048 & 0,798 \\
\hline Staż pracy od 6-10 lat*powyżej 10 lat & 0,838 & 0,133 & 0,752 \\
\hline Zakład pracy MOW*MOS & 0,829 & 0,737 & 0,694 \\
\hline Zakład pracy MOW*ZP & 0,021 & 0,178 & 0,029 \\
\hline Zakład pracy MOS*ZP & 0,015 & 0,308 & 0,010 \\
\hline
\end{tabular}

Źródło: opracowanie własne.

Odnotowano, że różnice statystycznie istotne odnoszą się do wyboru cechy 2 i dotyczą stażu pracy do 5 lat*powyżej 10 lat oraz w przypadku cechy 1 i 3 pomiędzy wskazaniami pracowników z MOW*ZP i MOS*ZP. Pracownicy z małym stażem pracy do 5 lat istotnie częściej odrzucają cechę 2 modelu konfliktowego niż pracownicy z większym stażem powyżej 10 lat pracy, a także wychowawcy z MOW i MOS istotnie częściej nie akceptowali cechy 1 i 3 omawianego sposobu socjalizacji niż pracownicy z ZP.

Tab. 10. Ocena poszczególnych cech modelu socjalizacji zupełnej swobody ze względu na płeć, wykształcenie, staż i zakład pracy badanych wychowawców

\begin{tabular}{|l|c|c|c|c|}
\hline \multicolumn{1}{|c|}{ Model socjalizacji zupełnej swobody } & Cecha 1 & Cecha 2 & Cecha 3 & Suma \\
\hline Badane osoby & $-1,60$ & $-1,47$ & $-0,29$ & $-3,36$ \\
\hline Kobieta & $-1,76$ & $-1,35$ & $-0,17$ & $-3,28$ \\
\hline Mężczyzna & $-1,41$ & $-1,57$ & $-0,40$ & $-3,38$ \\
\hline Wykształcenie w zakresie resocjalizacji & $-1,46$ & $-1,47$ & $-0,30$ & $-3,23$ \\
\hline Wykształcenie inne niż resocjalizacyjne & $-1,77$ & $-1,43$ & $-0,27$ & $-3,47$ \\
\hline Staż pracy do 5 lat & $-1,49$ & $-1,53$ & $-0,53$ & $-3,55$ \\
\hline Staż pracy od 6 do 10 lat & $-1,60$ & $-1,32$ & 0,03 & $-2,89$ \\
\hline Staż pracy powyżej 10 lat & $-1,57$ & $-1,52$ & $-0,46$ & $-3,55$ \\
\hline MOW & $-1,35$ & $-1,18$ & $-0,49$ & $-3,03$ \\
\hline MOS & $-1,35$ & $-1,32$ & $-0,42$ & $-3,10$ \\
\hline ZP & $-2,18$ & $-1,99$ & 0,28 & $-3,90$ \\
\hline
\end{tabular}

Źródło: opracowanie własne. 
Wychowawcy płci męskiej zaopiniowali model zupełnej swobody na poziomie $(-3,38)$, a suma tego typu oddziaływań dla kobiet wyniosła $(-3,28)$. Mężczyźni częściej niż kobiety odrzucali ten rodzaj socjalizacji.

Respondenci $\mathrm{z}$ wykształceniem $\mathrm{w}$ zakresie pedagogiki resocjalizacyjnej wskazywali na socjalizację o charakterze zupełnej swobody z wynikiem $(-3,23)$, zaś ankietowani z wykształceniem innym niż w zakresie pedagogiki resocjalizacyjnej określili omawiany model na poziomie $(-3,47)$. Wychowawcy z wykształceniem $\mathrm{w}$ zakresie pedagogiki resocjalizacyjnej rzadziej niż opiekunowie z wykształceniem innym niż w zakresie pedagogiki resocjalizacyjnej negowali ten typ socjalizacji.

Ze względu na czas pracy wszystkie grupy odniosły się do modelu zupełnej swobody negatywnie. Wychowawcy ze stażem do 5 lat oraz powyżej 10 lat pracy wyznaczyli sumę standaryzacji na poziomie $(-3,55)$. Natomiast osoby badane ze stażem pracy od 6 do 10 lat nieco wyżej sytuowały ten rodzaj oddziaływania, gdyż zaopiniowały go z kategorią $(-2,89)$.

Przez wychowawców z MOW typ socjalizacji zupełnej swobody został przyjęty na poziomie $(-3,03)$, pracownicy MOS określili jego sumę z kategorią $(-3,10)$. Najmniej był ceniony przez respondentów z ZP, gdyż z wynikiem $(-3,90)$. Wszystkie badane grupy ustosunkowały się negatywnie do socjalizacji o takim rodzaju oddziaływań.

Zasadniczo każda cecha modelu socjalizacji zupełnej swobody została odrzucona przez wychowawców. Wyjątek stanowi cecha 3, ponieważ została ona zaakceptowana tylko przez pracowników ze stażem od 6 do 10 lat pracy na poziomie $(0,03)$ oraz przez respondentów z ZP z wynikiem $(0,28)$.

Tab. 11. Istotność różnic pomiędzy wyborem poszczególnych cech modelu socjalizacji zupełnej swobody a płcią, wykształceniem, stażem i zakładem pracy badanych wychowawców

\begin{tabular}{|l|c|c|c|}
\hline \multicolumn{1}{|c|}{ Model socjalizacji } & \multicolumn{3}{c|}{ Istotność dwustronna } \\
\hline Zupełnej swobody & Cecha 1 & Cecha 2 & Cecha 3 \\
\hline Płeć & 0,114 & 0,246 & 0,555 \\
\hline Wykształcenie & 0,512 & 0,374 & 0,933 \\
\hline Staż pracy do 5 lat*6-10 lat & 0,438 & 0,656 & 0,201 \\
\hline Staż pracy do 5 lat*powyżej 10 lat & 0,944 & 0,804 & 0,789 \\
\hline Staż pracy od 6-10 lat*powyżej 10 lat & 0,455 & 0,793 & 0,224 \\
\hline Zakład pracy MOW*MOS & 0,913 & 0,562 & 0,757 \\
\hline Zakład pracy MOW*ZP & 0,123 & 0,189 & 0,003 \\
\hline Zakład pracy MOS*ZP & 0,149 & 0,048 & 0,006 \\
\hline
\end{tabular}

Źródło: opracowanie własne. 
Różnice statystycznie istotne zachodzą w przypadku wyborów cechy 2 i 3 między odpowiedziami pracowników z MOW*ZP i MOS*ZP. Cechę 2 modelu socjalizacji zupełnej swobody istotnie częściej odrzucali pracownicy ZP niż wychowawcy z MOS, zaś cecha 3 była istotnie częściej nieakceptowana przez respondentów z ZP niż przez pracowników MOW i MOS.

\section{ZAKOŃCZENIE}

Dominującym modelem socjalizacji wśród wychowawców resocjalizujących jest wariant lepienia z gliny, który otrzymał akceptację na poziomie $(2,13)$. Dwie pierwsze jego cechy uzyskały najwyższy stopień uznawalności, natomiast cecha 3 nie została przyjęta pozytywnie. Na drugim miejscu, z sumą standaryzacji $(1,41)$, usytuował się model wzajemności, ponieważ każdy jego atrybut był zaakceptowany. Pierwszym odrzuconym modelem jest rodzaj socjalizacji konfliktowy z kategorią $(-0,08)$ - jego cechy 1 i 3 zostały odrzucone, zaś cecha 2 została zaakceptowana. Drugim typem, który nie uzyskał aprobaty, jest model zupełnej swobody z sumą standaryzacji $(-3,36)$. W tym przypadku wszystkie jego treści zostały przez respondentów zanegowane.

Różnice statystycznie istotne odnotowano w podejściu wychowawców do stopnia akceptacji cechy 2 i 3 modelu lepienia $\mathrm{z}$ gliny. Ankietowani pracujący w ZP istotnie niżej wskazywali cechę 2, zaś cechę 3 ustanowili wyżej niż ich koledzy z MOW i MOS.

Różnic istotnie statystycznych nie stwierdzono w rangowaniu poziomów akceptacji poszczególnych cech modelu wzajemności.

Wystąpiły różnice statystycznie istotne w preferowaniu cechy 2 i 3 modelu konfliktowego. Osoby z niższym stażem pracy istotnie niżej szacowały cechę 2 niż respondenci z bardziej zaawansowanym stażem pracy powyżej 10 lat, zaś wychowawcy pracujący w ZP istotnie wyżej ocenili cechę 2 i 3 niż opiekunowie z ośrodków MOW i MOS.

W odniesieniu do modelu zupełnej swobody należy stwierdzić, że różnice statystycznie istotne zachodzą w stosunku do stopnia aprobaty cechy 2 i 3 . Wychowawcy pracujący w ZP istotnie niżej punktowali cechę 2, a cechę 3 ustanowili wyżej niż osoby ankietowane z MOW i MOS.

Przeprowadzone analizy miały dość uproszczony charakter, niemniej wskazały na potrzebę głębszego zanalizowania sytuacji. Należałoby doprecyzować badania, zwracając większą uwagę na istotę oddziaływań socjalizacyjnych, z uwzględnieniem specyfiki resocjalizacyjnej prowadzonej w placówkach o zróżnicowanym charakterze naprawczym, opiekuńczym, wychowawczym lub terapeutycznym. 


\section{BIBLIOGRAFIA}

Bandura A. (1973), Aggression: A Social Leaving Analysis, New York: Prentice-Hall.

Bronfenbrener U. (1970), Czynniki społeczne w rozwoju osobowości, „Psychologia Wychowania", nr 1.

Czapów C. (1978), Wychowanie resocjalizujace, Warszawa: PWN.

Likert R. (1932), A technique for the measurement of attitudes, “Archival of Psychology”, No. 40.

Marks K., Engels F. (1961), Ideologia niemiecka, [w]: Dzieła, t. 3, Warszawa: PWN.

Pytka L. (2005), Pedagogika resocjalizacyjna, Warszawa: APS.

Schaffer H.R. (2006), Rozwój społeczny, dzieciństwo i młodość, Kraków: Wydawnictwo Uniwersytetu Jagiellońskiego.

Sobczak S. (2000), Celowość wychowania, Warszawa: Wydawnictwo Navo.

Sobczak S. (2002), Filozoficzne i teologiczne aspekty dzieciństwa, [w]: B. Głowacka, L. Pytka (red.), Być dzieckiem i przetrwać, Warszawa: KKWR.

Sobczak S. (2009), Aksjologia i teleologia pedagogiki resocjalizacyjnej, Warszawa: Wydawnictwo Pedagogium.

Sobczak S. (2011), Teoretyczne podstawy przyczyn przemocy $w$ ujęciu realistycznym $w$ aspektach czynników biopsychicznych i socjokulturowych, [w]: R. Kowalski, O. Szynkarczyk (red.), Wychowanie we współczesnej szkole. Szkoła wolna od przemocy, Siedlce: Wydawnictwo UPH.

Zaborowski Z. (1969), O rodzinie. Rodzina jako grupa społeczno-wychowawcza, Warszawa: Wydawnictwo Nasza Księgarnia.

\section{SUMMARY}

This article concerns the issues of socialisation influences in the institutional structure. Scholars have not conducted before this type of research on the preferences of particular types of socialisation. In the literature there is only described the scientific basis which presents theoretical approaches concerning particular ways of socialisation influences. Therefore, it was decided to create a research tool which was designed based on Schaffer's statements. Then, it was also needed, on the basis of Schaffer's statements, to determine what pattern of four varieties of socialisation is preferred by educators from social rehabilitation institutions? The aim was to determine statistically significant differences between the degree of acceptance of particular socialisation types by virtue of gender, seniority and workplace of educators specialising in social rehabilitation. As a hypothesis it was assumed that there are statistically significant differences between the ranks which were ascribed to particular models of socialisation on the grounds of age, seniority and workplace of educators specialising in social rehabilitation. The study constitutes a research perspective of theoretical description of socialisation types presented in the literature.

Keywords: socialisation; impact of educators; social rehabilitation 